\title{
Immunities And Arbitration: A New Lex Specialis Regime
}

\author{
Satya Talwar Mouland ${ }^{1}$ \\ ${ }^{1}$ School of Law, Queen Mary University of London, London, United Kingdom \\ Corresponding author: s.mouland@qmul.ac.uk
}

(Received 01 July 2020; accepted 25 October 2020)

\begin{abstract}
The interaction between immunities and jurisdiction is complex. One lacuna is whether the international legal principle of state immunity is a rule or principle in its own right or an exception to a pre-existing jurisdiction. In the context of international arbitration disputes, this distinction is significant. States have been relying on immunity to exclude the jurisdiction of national courts to support the international arbitral process. This Article argues there is now a growing set of common and consistent practice according to which state immunity operates as a rule or principle lex specialis to a more general set of rules or principles governing the enforcement jurisdiction of national courts.
\end{abstract}

Keywords: State immunity; enforcement jurisdiction; adjudicative jurisdiction; public international law; international arbitration; private international law; lex specialis; national courts

\section{A. Introduction}

Immunities have long played a role in the adjudicative processes of national courts. In the Arrest Warrant decision, Judge Rezek noted that "no immunity is absolute ... an immunity must necessarily exist within a particular context, and no subject of law can enjoy immunity in the abstract. Thus, an immunity might be available before one national court but not before another." At the same time, this does not speak to whether immunity is an "exception to jurisdiction or a principle of law in its own right, so forming part of, rather than exception, to, jurisdiction." 2 One might ask the question of why-in what context-would such a determination matter.

This Article seeks to address that question by arguing that the international legal principle of state immunity is emerging as a rule lex specialis to a more general set of rules or principles concerning "enforcement jurisdiction" of national courts in respect of international arbitral tribunals. No distinction will be made between "rules" and "principles" in this work. Rather, the "rules" are understood as norms which guide a solution to legal problems finally-that is, without any room for argument either way-while "principles" bring out arguments in favour of one way or another and thus do not determine a solution finally. ${ }^{3}$ Both will be assumed as binding as a matter of law.

\footnotetext{
Ms. Talwar Mouland is a final year PhD student at Queen Mary University of London (Principal's Scholar) and current BVS student at City University (City and Middle Temple Scholar).

${ }^{1}$ Arrest Warrant of 11 April 2000 (Dem. Rep. Congo v. Belg.), Judgment, 2002 I.C.J. para. 2 (Feb. 14) (separate opinion by Rezek, J.).

${ }^{2}$ Hazel Fox \& Philippa Webb, The Law Of State Immunity 84 (2013).

${ }^{3}$ See Marti Koskenniemi, From Apology to Utopia: The Structure of International Legal Argument 37 (2005). An exception is made for the "international legal principle of state immunity" which will named as such because it is often called a "principle" in the literature, though no inference as to its legal nature (other than that it is binding) should be drawn from this label.
}

(c) The Author(s) 2022. Published by Cambridge University Press on behalf of the German Law Journal. This is an Open Access article, distributed under the terms of the Creative Commons Attribution licence (https://creativecommons.org/licenses/by/4.0/), which permits unrestricted re-use, distribution, and reproduction in any medium, provided the original work is properly cited. 
"Enforcement jurisdiction" is being defined herein as the power of states to induce or compel compliance, including through their courts. This notion of 'compliance' is reflected as a norm which underpins inter-state relations more generally, ensuring a state's compliance with international law norms. ${ }^{4}$ It is also reflective of private international law approaches, for example the regulation of enforcement of foreign judgments, such as in the Brussels I (Recast) Regulation. ${ }^{5}$ In the arbitration context, this would include any measures which seek to induce or compel the state's compliance with the international arbitral process or award. ${ }^{6}$ Conversely, in traditional public international contexts, "enforcement jurisdiction" is considered more narrowly as the authority to compel or coerce the state to do something. ${ }^{7}$ Here, it is being considered as a power which includes inducing compliance of the state with foreign laws, including international law, insofar as it is part of that law. Thus, where "enforcement jurisdiction" is mentioned herein, it will connote this wider concept unless otherwise identified as relating to the narrower public international law concept.

The international legal principle of immunity provides that a state may not exercise its jurisdiction in the territory of another state because that would be a breach of the foreign state's sovereignty. ${ }^{8}$ The tool of "lex specialis" as a mechanism for placing special "secondary" rules within the context of a more general set of rules has been explored by Simma and Pulkowski in their article "SelfContained Regimes in International Law." This is generally the idea that there may be "special" regimes of law which operate within the context of a more general set of rules, with the consequence that that general set of rules applies residually when the special set of rules are at play.

The emergence of any such rules or principles - which would oblige a national court to exercise enforcement jurisdiction in respect of international arbitral tribunals-has important analytical and practical consequences for court proceedings related to international arbitrations. Two of the largest arbitration awards in history, rendered in the Yukos and Stati decisions, have led to protracted enforcement litigation across the globe. Many of the problems encountered relate to whether states could rely on the international principle of immunity to exclude the enforcement jurisdiction of national courts, including when a valid arbitration award had been rendered.

In Yukos, the Russian company obtained three arbitration awards worth $\$ 50$ billion against the Russian state pursuant to the Energy Charter Treaty. Having been set aside by the Moscow Arbitrazh court, Yukos sought to enforce the award in a number of other municipal courts. These courts have refused to recognize the award as enforceable, adopting interpretations of national state immunity laws - which give effect to the international legal principle of state immunity - to exclude the jurisdiction. ${ }^{10}$ Similarly, in Stati, Moldovan creditors sought to enforce a $\$ 500$ million award obtained in Sweden against Kazakhstan. Although attachment was successful in the Swedish court, ${ }^{11}$ there are outstanding proceedings arising out of prior failed

\footnotetext{
${ }^{4}$ See, e.g., Harold Koh, 'Why Do Nations Obey International Law?' (1997) Faculty Scholarship Series Paper 2101.

${ }^{5}$ Regulation (EU) No 1215/2012 of the European Parliament and of the Council of 12 December 2012 on jurisdiction and the recognition and enforcement of judgments in civil and commercial matters.

${ }^{6}$ This is covered only partially by the arbitration literature which focuses on the private international law rules which govern when a particular state may recognize or enforce an arbitration award or grant interim relief, though execution measures are not discussed nor is a public international law perspective. See, e.g., Gary B. Born, International Commercial Arbitration chs. 17, 26 (2d ed. 2014); Nigel Blackaby, Constantine Partasides, Alan Redfern \& Martin Hunter, Redfern and Hunter on International Commercial Arbitration chs. 7, 11 (6th ed. 2015).

${ }^{7}$ Fox \& WeBB, supra note 2, at 484-87; Jeremy Ostrander, The Last Bastion of Sovereign Immunity: A Comparative Look at Immunity from Execution of Judgments, 22 BERKELEY J. INT'L L. 541 (2004), at 546 (discussing the potential effect of such jurisdiction on diplomatic relations); Michael Akehurst, 'Jurisdiction in International Law' (1972-1973) 46 Brit Y B Int'l L 145.

${ }^{8}$ Fox \& WeBB, supra note 2 , at 1.

${ }^{9}$ Bruno Simma \& Dirk Pulkowski, Of Planets and the Universe: Self-contained Regimes in International Law, 17 EUR. J. INT'L L. 483 (2006).

${ }^{10}$ See, e.g., Tribunal de Première Instance [Civ.] [Tribunal of First Instance] Brussels, Yukos Universal v. Russ. (lifting orders for attachment based on interpretation of national state immunity laws).

${ }^{11}$ Tingsrätt [TR] [District Court] 2018-01-24 T 10498-17 (Swed.), https://www.italaw.com/sites/default/files/casedocuments/italaw11232.PDF.
} 
attachments in other courts, including in the UK and US. For example, in one recent decision of the UK court, attachment against assets for which Dutch and Belgian orders had already been made, was refused by the court. ${ }^{12}$ Thus, there is protracted litigation on the issue of enforcement of arbitral awards and differing approaches under national laws. This is despite the fact that this issue - of which court, and on what basis, ought to have jurisdiction — crosses borders since the arbitration may occur outside the jurisdiction of the enforcing court. ${ }^{13}$

\section{Methodology}

From the perspective of public international law, adjudicative jurisdiction is no more than a facet of a state's prescriptive jurisdiction - its authority to adopt laws. ${ }^{14}$ Any wider contribution of national courts to international law beyond interpreting national laws thus may be doubted, at least from the perspective of viewing national courts decisions as merely interpretative or declaratory of international law. ${ }^{15}$ The same approach is taken in private international law, where court jurisdiction is usually analyzed from the internal perspective of the sovereign state. This concerns the question of whether that court may apply a foreign law or extend its jurisdiction over a foreign situation. ${ }^{16}$ From this perspective, the interaction between arbitration and immunity is unclear. ${ }^{17}$ For example, in the principal textbook on state immunity, Fox and Webb have analyzed the extent to which national court decisions have expressly stated that particular powers are available. ${ }^{18}$ This does not analyze the wider question of whether adjudicative jurisdiction-the power of states to exercise decision-making authority through their courts-may be a manifestation of any consistent rules or principles of enforcement jurisdiction.

This article instead takes an approach which cuts across public and private international law, ${ }^{19}$ considering the extent to which adjudicative jurisdiction may be declaratory of norms of enforcement jurisdiction from the perspective of "harmonization" of law. "Harmonization" for these purposes is "the process of ascertaining the admitted limits of international unification but does not necessarily amount to a vision of total uniformity." ${ }^{20}$ In this context, national court approaches to their enforcement jurisdiction from the private international law perspective will be

\footnotetext{
${ }^{12}$ Nat'l Bank of Kaz. v. Bank of New York Mellon [2017] EWHC (Comm.) 3512 (Eng.).

${ }^{13}$ For example, in Stati, it was an arbitration under the Stockholm Chamber of Commerce Rules, though enforcement has been sought in UK and US courts, where assets may be located. See Tingsrätt [TR] [District Court] 2018-01-24 T 10498-17 (Swed.), https://www.italaw.com/sites/default/files/case-documents/italaw11232.PDF.

${ }^{14}$ See, e.g., Christoper Staker, Jurisdiction, in InTERnational Law 313 (Malcom Evans ed., 4th ed. 2014); MALCOLM N. SHAw, InTERnAtional LAW 472 (8th ed. 2018); Michael Akehurst, Jurisdiction in International Law, 46 BRIT. Y.B. INT'L L. 145 (1972-73); Oppenheim's InTERnATIONAL LAW 45 (Robert Jennings \& Arthur Watts KCMG QC eds., 9th ed. 1992).

${ }^{15}$ See, e.g., Roger O'Keefe, Domestic Courts as Agents of Development of the International Law of Jurisdiction, 26 LEIDEN J. INT'L L. 541 (2013).

${ }^{16}$ Dicey, Morris and Collins on The Conflict of Laws 371 (Lord Collins of Mapesbury, David McClean, C G J Morse, Adrian Briggs, Jonathan Harris, Campbell McLachlan, Andrew Dickinson, \& Peter McEleavy eds., 15th ed. 2012); Andrew Dickinson, Keeping Up Appearances: The Development of Adjudicatory Jurisdiction in the English Courts, 86 BRIT. Y. B. INT'L L. 6, 7 (2017).

${ }^{17}$ Fox \& WEBB, supra note 2, at 392-93.

${ }^{18} I d$.

${ }^{19}$ This approach which considers private international law as part of public international law is not new in principle; see Alex Mills, The Confluence of Public and Private International Law: Justice, Pluralism and Subsidiarity in the international Constitutional Ordering of Private LaW (2009).

${ }^{20}$ Werner F. Menski, Comparative LaW in a Global Context 39 (2006). This is distinct from how "harmonization" might be understood in a number of legal contexts, as simply identifying the extent to which existing legal frameworks have created common approaches. See, e.g., Marcus Klamert, What We Talk About When We Talk About Harmonisation, 17 CAMbridge Y.B. Euro. Legal STUd. 360 (2015). No matter which form of harmonization is discussed in the EU context, it generally relates to an aim concerning common standards. Instead, this article analyzes whether exercises of decision-making authority by courts may be "harmonized" in light of international legal norms-and not simply the question of the extent to which those exercises follow any particular international legal norm. In this sense, the national court decisions are the primary source of any such norms.
} 
considered a source of any potential public international law "rule" or "principle." This approach will be developed throughout this Article with a view to demonstrating its utility in understanding the scope of enforcement jurisdiction of states, as exercised through their courts, in the context of international arbitration.

Moreover, this Article adopts the functional comparative method to identify any consistent practice between the chosen courts. ${ }^{21}$ Ralf Michaels has implied that the use of the functional comparative method is less useful for achieving unity in law than it is for understanding and comparing laws. Considering adjudicative jurisdiction as enforcement, this Article instead suggests that the functional comparative method may be useful for identifying commonalities and trends at the intersection between state immunity and arbitration.

There are various harmonizing instruments relating to the scope of enforcement powers of national courts in the context of international arbitrations, whether between private parties or states: The United Nations Commission on International Trade Law ('UNCITRAL') Model Law on International Commercial Arbitration-as amended in $2006-{ }^{22}$ the Convention on the Recognition and Enforcement of Arbitral Awards, ${ }^{23}$ and the UN Convention on Jurisdictional Immunities of States and Their Properties. ${ }^{24}$ To examine the harmonization of any common national court approaches, the extent to which four representative state approaches to adjudicative jurisdiction are reflective of any enforcement norms will be examined in light of these harmonizing instruments: UK (as a non-federal common law State), US (federal common law), France (non-federal (civil law), and Germany (federal civil law and UNCITRAL Model Law).

\section{Structure}

This Article is structured according to different enforcement powers which national courts may exercise in respect of international arbitral tribunals: supervisory jurisdiction, such as interim measures and measures to compel the arbitration to proceed; recognition and review jurisdiction, to declare any rendered award enforceable or to review its validity in accordance with the applicable law; and execution jurisdiction, to ensure that assets against which enforcement is sought may be attached.

\section{B. Supervisory Jurisdiction}

The main harmonizing instrument for interim relief and other measures which seek to support the international arbitration proceeding is the UNCITRAL Model Law. Legislation based on the Model Law has been adopted by eighty-three states of the total 116 Contracting States. In respect of interim relief, Article 17 J provides: "A court shall have the same power of issuing an interim measure in relation to arbitration proceedings, irrespective of whether their place is in the territory of this State."

Moreover, there is a general principle in Article 8 Model Law which provides that an action before a court which has been subject to an arbitration agreement must be referred by that court to arbitration unless it finds that the agreement is "null or void, inoperative or incapable of being performed." This also reflects the principal exception for refusing to enforce an arbitration agreement within the meaning of Article II(3) New York Convention.

\footnotetext{
${ }^{21}$ See Ralf Michaels, The Functional Method of Comparative Law, in THE OXFORD HANDBOOK OF COMPARATIVE LAW 339-82 (2006).

${ }^{22}$ Rep. of Comm'n on Int'l Trade L., Model L. on Int'l Com. Arb. 1985, U.N. Doc. A/40/17, Annex I (June 21, 1985) [hereinafter Model Law].

${ }^{23}$ U.N. Convention on the Recognition and Enforcement of Foreign Arbitral Awards, June 10, 1958, 21 U.S.T. 2517, 330 U.N.T S. 3 (1959) [hereinafter New York Convention].

${ }^{24}$ United Nations General Assembly, United Nations Convention on Jurisdictional Immunities of States and Their Property, Dec. 2, 2004, A/RES/59/3. This has not yet entered into force as only 21 of 30 necessary states are State Parties [hereinafter UNCSI].
} 
The availability of supportive forms of jurisdiction in respect to international arbitrations is generally important in a number of common scenarios which may arise: the arbitral tribunal might not yet be constituted and thus parties might need to apply to a national court for interim relief, the case might be one of "urgency" such that the arbitral tribunal cannot act swiftly enough, ${ }^{25}$ or where the particular measure sought can only be sought in a particular national court. ${ }^{26}$

Article 17 J Model Law clearly places an obligation on all national courts-regardless of where they are located-to exercise jurisdiction to grant interim relief. UK, US, and French private international law rules follow this approach more widely in relation to different forms of supervisory jurisdiction including orders to compel the arbitration to proceed, stays, ${ }^{27}$ and prejudgment attachment. Examples in the UK, US, and French courts will be taken in turn as examples which illustrate different powers encompassed by the notion of "supervisory jurisdiction."

Section 2(3) English Arbitration Act (EAA) provides that interim measures are available "even if the seat of arbitration is outside England and Wales or Northern Ireland." The availability of such relief regardless of any private international law link between the territory of the court and the arbitration has been recognized, for example, in the Pearl Petroleum decision. ${ }^{28}$ This is representative of the wider UK court approach in this area, where various forms of supportive relief have been granted or recognized as available regardless of any territorial connection to the court or in respect to a foreign State. ${ }^{29}$ In an ongoing London Court of International Arbitration (LCIA) arbitration against the Kurdistan Republic, a Swiss company applied to a UK court for a peremptory order. This is a particular form of supportive relief which is issued by courts to ensure compliance with the arbitral tribunal's instructions. Even though the measure was sought in respect to a foreign state, to which the principle of state immunity might ordinarily apply given that a foreign state was being brought before a UK court, the court exercised its jurisdiction to grant the measure in accordance with Section 44(5) EAA. This provides that a court may act to the extent that an arbitral tribunal is unable to act effectively. Thus, by exercising its decision-making authority to grant the peremptory order as to the foreign state, the exercise might be viewed as implicit acceptance that the particular form of enforcement-supportive relief-falls within the scope of the court's authority.

There is no comparable express provision in the US Federal Arbitration Act (FAA) ${ }^{30}$ However, consistent practice of US courts demonstrate that supportive forms of jurisdiction are available regardless of any territorial connection to the jurisdiction. The 2011 decision in Republic of Ecuador v. Chevron Corporation ${ }^{31}$ Is illustrative of this approach. Chevron Corporation invoked arbitration against Ecuador pursuant to a bilateral investment treaty (BIT) between the United States and Ecuador. Concurrently, a group of Ecuadorian individuals filed claims in Ecuador against Texaco Petroleum Company (TexPet), a wholly owned subsidiary of Chevron, for environmental damage allegedly caused by its activities in Ecuador, known as the Lago Agrio litigation. In the arbitration, Chevron asserted that any judgment against it in the Lago Agrio litigation would violate the terms of a settlement agreed upon between Ecuador and TexPet. The question as to whether the initiation of the BIT arbitration breached the Lago Agrio litigation came before the

\footnotetext{
${ }^{25}$ This circumstance is foreseen in Arbitration Act 1996, $\$ \$ 23,44(3)$ (UK) [hereinafter EAA], which provides this expressly as a basis upon which a United Kingdom court may, at its discretion, order such measures as it "thinks necessary" to remedy any such urgency.

${ }^{26}$ This would include, for example, attachment orders against assets situated in the jurisdiction of that court.

${ }^{27}$ These are particular orders which can be made in courts of common law jurisdiction to halt proceedings which may have been commenced in breach of the arbitration agreement. See, e.g., EAA, supra note 29, at sec. 9.

${ }^{28}$ Pearl Petroleum, Dana Gas PJSC \& Crescent Petroleum Co. Int'l Ltd. v. Kurdistan Reg'l Gov’t of Iraq [2015] EWHC (Comm.) 3361 (Eng.).

${ }^{29}$ See, e.g., Mobil Cerro Negro Ltd v. Petroleos De Venezuela SA [2008] EWHC (Comm.) 532, paras. 18-19 (Eng.) (freezing injunction available, in principle, according to Section 44 EAA and Section 37 Senior Courts Act 1981 (c. 54) [hereinafter SCA 1981]; BNP Paribas S.A. v. Open Joint Stock Com. Russian Machines [2011] EWHC (Comm.) 308 (Eng.) (relating to anti-suit injunctions, the court found these were available pursuant to the court's inherent power under $\$ 37$ SCA 1981).

${ }^{30}$ Federal Arbitration Act 9 U.S.C.A., ch. 213, 43 Stat. 883 (1925).

${ }^{31}$ Republic of Ecuador v. Chevron Corp., 638 F.3d 384 (2d Cir. 2011).
} 
US court. While acknowledging its parallel power to stay the arbitration proceedings, ${ }^{32}$ the court found that Chevron was not estopped ${ }^{33}$ from relying on its right to arbitrate by virtue of its initiation of the litigation in Lago Agrio. ${ }^{34}$ Conversely, the court would be obliged to enforce the valid arbitration agreement to which the parties consented under the BIT because this constitutes an "agreement in writing" for the purposes of Article II New York Convention. ${ }^{35}$ Article II(3) provides that courts must refer parties to arbitration where there is an arbitration agreement unless that agreement is "null, void, inoperative or incapable or being performed." The court found that it could uphold the arbitration agreement and the questions of waiver and estoppel relating to the Lago Agrio litigation were threshold issues for the arbitral tribunal. ${ }^{36}$ Consequently, in effect, the exercise of decision-making authority with respect to the foreign state -Ecuador - upheld the arbitration proceeding regardless of the principle of immunity. ${ }^{37}$

The Soguipêche decision ${ }^{38}$ demonstrates the French approach. This concerned an ongoing arbitration under the International Convention on the Settlement of Investment Disputes between States and Nationals of Other States (ICSID). Atlantic Triton sought an arbitration against the Republic of Guinea which had issued a legislative decree entrusting certain vessels due to Atlantic Triton instead to Société guinéenne de pêche (Soguipêche). The Court at Rennes had granted Atlantic Triton a security measure attaching three vessels of Guinea in France. Guinea challenged this decision. The French Cour de Cassation (Supreme Court) annulled the decision on the ground that a party which consents to ICSID excludes the supportive jurisdiction of national courts. According to Article 26 ICSID, consent to arbitration under the ICSID Convention shall be deemed consent to the exclusion of any other remedy. However, the court does not exclude-and in fact implicitly accepts through exercise of its decision-making authority - that such jurisdiction would not be excluded, in principle, with respect to a foreign state. This is because its jurisdiction is not considered as ipso facto excluded by principles of immunity but instead is a question which the court may review in accordance with the applicable arbitration rules which the parties have selected. In this case, because the parties selected ICSID—to which a special rule excluding supportive jurisdiction applied - the jurisdiction was interpreted as excluded. However, outside ICSID, the general approach of French courts has-like the United Kingdom and United States court approaches-been to render supportive forms of relief regardless of any link to the jurisdiction. ${ }^{39}$

This set of consistent practice between the representative courts demonstrates the general availability of forms of supportive relief in respect to international arbitrations regardless of any link to the jurisdiction, or where one of the parties is a state. In this context, the international principle of immunity has been interpreted as inapplicable to the question of court jurisdiction. According to

\footnotetext{
${ }^{32} I d$. at 388 .

33"Estoppel" meaning that a party is not precluded from relying on an argument which it has relied on to different effect in another context. For example, by entering into a litigation, the question is whether such would exclude or negate the agreement to arbitrate.

${ }^{34}$ Republic of Ecuador, 638 F.3d at 389-90.

${ }^{35} I d$., at 391.

${ }^{36} I d$. at 392.

${ }^{37}$ In relation to other forms of supportive jurisdiction and in relation to injunctive relief: Toyo Tire Holdings of Am., Inc. $v$ Cont'l Tire N. Am., 609 F.3d 975 (9th Cir. 2010) (granting injunctive relief granted to the maintain the "meaningfulness" of an ICC arbitration); Stemcor USA, Inc. v. Cia Siderurgica do Para Cosipar, 927 F.3d 906 (5th Cir. 2018) (granting an attachment order in a New York arbitration in order to make the arbitration "as effective as possible.") The decision in Stemcor USA, for what it said, may also be used as evidence of this growing rule relating to supporting the arbitral proceeding.

${ }^{38}$ Cour de cassation [Cass.] [supreme court for judicial matters] Civile, 1 Chamber, Nov. 18, 1986, ARB/84/1 (Fr.).

${ }^{39}$ See, e.g., Southern Pacific Props., Ltd. v. Arab Republic of Egypt, 3 ICSID Rep. 131 (1995); Emmanuel Gaillard, France: Court of Cassation Decision in Southern Pacific Properties Ltd. et al.. v. Arab Republic of Egypt (Appellate Review of Arbitral Awards between States and Private Parties), 26 ILM 1004 (1987) (court considered whether it could set aside an ICC award rendered in Egypt, reviewing Egypt's capacity to enter into the arbitration agreement and thus accepting its power of review in the context of setting aside proceedings); Cour d'appel [CA] [regional court of appeal] Paris, June 16, 1988, Swiss Oil Corp. v. Société Petrogab (confirming the admissibility of setting aside proceedings against a foreign State pursuant to an ICC arbitration) (Fr.).
} 
the practice examined, this would include pre-judgment attachment orders, review of awards in the context of setting aside proceedings, orders to compel an arbitration to proceed and peremptory orders. These measures merely seek to support the arbitral proceeding and do not coerce a foreign state in any way. ${ }^{40}$

\section{Recognition and Review Jurisdiction}

Once the award has been rendered, states must generally comply. However, not infrequently, these awards must be converted into national court judgments such that they can be used to force states to comply with the award via execution measures ${ }^{41}$ such as third-party debt orders should they fail to comply. ${ }^{42}$ The question arising in this part is whether there is now a more general set of practices which suggests that any national court may exercise that power even when there is no connection to their territorial jurisdiction.

Article I(1) New York Convention provides the obligation on contracting states to recognize and enforce arbitration awards "made in the territory of a State other than the State where the recognition and enforcement of such awards are sought." This implies that any court may, in principle, have jurisdiction to "recognize and enforce" arbitration awards irrespective of where they are made.

Two questions arise from this formulation. What is meant by "recognize and enforce"? And to what extent does state immunity play a role in limiting any such jurisdiction?

The consistent approaches of UK, US, French, and German courts have been clear in this regard. Beginning with the civil law states, the approach of their courts more directly considers the interaction between the international principle of state immunity and the scope of its courts' recognition jurisdiction within the meaning of Article I(1) New York Convention. A good example of this approach is the decision in Société Européenne d'Etudes. ${ }^{43}$ Société Européenne d'Etudes (SEEE) entered into an agreement with the Yugoslav Government for construction of a railway. When SEEE claimed additional payments and Yugoslavia refused to pay, SEEE sought an arbitration against Yugoslavia in Switzerland. An award was rendered against the Yugoslav Government. SEEE applied to the Tribunal de Grande Instance in Paris for leave to enforce the award. Leave to enforce is the equivalent of recognition and enforcement within the meaning of Article I(1) New York Convention as it ensures that the award is declared enforceable-though is not actually enforced against assets which is a separate power to be discussed below. The Yugoslav Government tried to invoke its jurisdictional immunity in an attempt to argue that recognition could not be granted with respect to the particular claims-relating to public works which it stated were intended to ensure the function of a traditional mission of the state being the constructor of a railroad. The court considered this question under the head of "immunity from jurisdiction," considering whether its jurisdiction would be excluded by the international legal principle of immunity. This is because in France, public international law relating to immunity is a direct source of the court's authority. ${ }^{44}$ There is no specific national legislative act enacting

\footnotetext{
${ }^{40}$ This is generally the basis upon which immunities are generally considered as being "absolute" in respect of enforcement jurisdiction, including that exercised through national courts. See, e.g., Fox \& WEBB, supra note 2, at 484; Ostrander, supra note 9.

${ }^{41}$ The "final step" in the enforcement process which will be discussed in Part IV below.

${ }^{42}$ See, e.g., Bundesgerichtshof [BGH] [Federal Court of Justice], Case No. III ZB 40/12, para. 14, (Jan. 30, 2013), https://juris. bundesgerichtshof.de/cgi-bin/rechtsprechung/document.py?Gericht=bgh\&Art=en\&sid=elcb08ce86eef36cafce617600cd6038\&nr= $63472 \&$ pos $=2 \& a n z=3$ (Ger.) In considering whether an award rendered against Thailand could be recognized as enforceable in Germany, the German court expressly considers the proceeding for declaring the award enforceable ("Vollstreckbarerklaerung") as the "necessary" step before a later execution proceeding ("Zwangsvollstreckung").

${ }^{43}$ Cour d'appel [CA] [regional court of appeal] Rouen, Nov. 13, 1984, 982/82 (Fr.).

${ }^{44}$ Court jurisdiction in this area derives from public international law: Code Civil [C. Civ.] [Civil Code] art. 33 (Fr.) [hereinafter CPC]; Loi 411-2 \$2 Code of Judicial Organisation [Cour de Cassation]; 1946 ConsT. $\$ 14$ (Fr.). Similarly, in Germany, the source is public international law: Article 20(2) Court Judicature Act and Grundgesetz [GG], translation at https://www. gesetze-im-internet.de/englisch_gg/englisch_gg.html\#p0141.
} 
immunity rules as part of the state's national law. Consequently, the court had the opportunity to directly consider the question of the scope of its recognition jurisdiction. In this regard, it found that it was sufficient that the Yugoslav Government consented to the arbitration in its private capacity; the content of those obligations was irrelevant. ${ }^{45}$ The court does consider the nature of the contract-whether it is public or private-which might imply that such a finding would change the scope of the court's power to recognize the award. ${ }^{46}$

However, a further set of consistent practice, to the effect that it is not the nature of the contract but the parties' particular consent to arbitration, which is conclusive for the exclusion of state immunity, is clear. For example, in the 2018 Société FG Hemisphere Associates decision, which is exemplary of this consistent approach, the question came before the Cour de Cassation as to whether it would violate Article 1699 Code Civile (civil code) for an arbitration award, recognized in Zurich, to be enforced against the Democratic Republic of Congo in France. Article 1699 provides the assignor of a debt the right to be released from that debt when the assignee pays the actual price of the assignment and interest. The court considered that its right to review this point of law arose in application of Articles 1520 and 1525 Code de procédure civile (CPC) which provide limitations on the power of French courts to review arbitration award. These are broadly reflective of those grounds found in Article V New York Convention. They include review based on procedural deficiencies in the arbitration (Article 1520(1)-(2)), that the tribunal acted beyond its powers (Article 1520(3)), and that the award was contrary to international public policy (Article 1520(5)). In this decision, the court determined that its scope of power to review the award was limited by these provisions. Thus, it could examine, in accordance with the French Civil Code, whether the decision on payment under the award violated Article 1699. By considering this question, the French court accepts that such a power, arising under Articles 1520 in respect of domestic arbitrations, also extends to arbitrations against states. Consequently, such powers of review-relating to the enforceability of the award-come within the scope of international adjudicative authority of the French court. ${ }^{47}$ The term 'international adjudicative authority' is being used here simply to connote how the jurisdiction is treated by the French court: since the public international law norm of state immunity is directly a source of the court's authority, the court deems itself as exercising its international' ${ }^{48}$ judicial competence to decide on the enforceability of the award. ${ }^{49}$

Similarly, the German approach can be illustrated by the decision in Walter Bau for what the court said (i.e., its reasoning) and not merely the effect of the decision (that is, the fact of its exercise 'in the public sphere', or in respect of the foreign State).$^{50}$ As with the French approach, German courts directly consider the question of their own jurisdiction in light of the international legal principle of immunity. This is, again, because there is no special national immunity law:

\footnotetext{
${ }^{45} I d$. at $26-27$.

${ }^{46} I d$. at $6-9$ (finding that they are, in any case, private).

${ }^{47}$ This rule or principle is reflected by a wider set of practice in which French courts consistently recognize their power to declare awards enforceable, including to review those awards in accordance with the applicable law. See Cour d'appel [CA] [regional court of appeal], Dec. 5, 1989, État du Sénégal v. Seutin, es-qual de liquidateur de la société S.O.A.B.I (Fr.); Cour de Cassation [Cass.] [supreme court for judicial matters], July 8, 2016, Société Ryanair Ltd et Société Airport Marketing Services Ltd v. Syndicat Mixte des Aéroports de Charente (Fr.); Cour d'appel [CA] [regional court of appeal] Paris, civ., Apr. 10, 2018, Société Alstom Transport SA et autre v. Société Alexander Brothers Ltd (Fr.) (affirmed that French courts may appeal orders for the recognition and enforcement of foreign arbitration awards on the basis that such an order would breach international public policy); Cour de Cassation [Cass.] [supreme court for judicial matters] 1e civ., Bull. civ. I, No. 16-22.112, République démocratique du Congo v. Société FG Hemisphere Associates LLC (Fr.).

${ }^{48}$ This is a specific nuance in the language of French and German courts when exercising jurisdiction in respect of foreign states.

${ }^{49}$ Code Civil [C. Civ.] [Civil Code] art. 33 (Fr.), Loi 411-2 \$2 Code of Judicial Organisation [Cour de Cassation], 1946; CONST. $\$ 14$ (Fr.).

${ }^{50}$ See, e.g., Bundesgerichtshof [BGH] [Federal Court of Justice], Case No. III ZB 40/12, para. 14, (Jan. 30, 2013), https://juris. bundesgerichtshof.de/cgi-bin/rechtsprechung/document.py?Gericht=bgh\&Art=en\&sid=e1cb08ce86eef36cafce617600cd6038\& $\mathrm{nr}=63472 \& \mathrm{pos}=2 \& \operatorname{anz}=3$ (Ger.).
} 
international law is directly the source of the court's authority in accordance with \$20(2) Courts Constitution Act and Article 25 Federal Constitution. Article 20(2) provides that German jurisdiction shall not apply to persons insofar as they are exempt therefrom according to "general rules of international law or on the basis of international agreements or other legislation." Walter Bau concerned the enforcement of an award rendered in Switzerland under a 2002 BIT between Thailand and Germany. Walter Bau, a German company, had invested in a project for construction of a tollway from Bangkok to Don Muang Airport. When Walter Bau was declared bankrupt, its liquidator, Werner Schneider, brought a claim to arbitration against Thailand based on the arbitration clause in the 2002 BIT, alleging that it had breached Walter Bau's rights in the tollway. Once an award was obtained against Thailand, Werner Schneider applied for a declaration of enforceability (Vollstreckbarerklärung) in the German court. The court expressly stated the German position with respect to the Vollstreckbarerklärung, which it distinguished from the Zwangsvollstreckung (execution or compulsory enforcement proceeding). The question pertained to availability of the jurisdiction according to applicable international law norms, including those of state immunity. Consequently, the interaction between the court's jurisdiction and international principles of state immunity was directly considered by the decision. The court found that because the parties had consented to recognition and enforcement of the arbitration award under $\$ 1061$ German Civil Procedure Rules ('ZPO'), which gives effect to Article I(1) New York Convention as part of German law as well as under its consent to arbitrate in the BIT, then immunity could not exclude German jurisdiction. ${ }^{51}$ This was on the ground that, should recognition be disallowed, this would contradict the very object and purpose of the Treaty upon which consent to the arbitration is based which included the obligation that the arbitration award would be enforced. The court ultimately granted the declaration of enforceability against the foreign state, which is representative of the general German court approach to this form of jurisdiction against states. ${ }^{52}$

Conversely, the UK and US approaches arise at the intersection between their national state immunity laws - the UK State Immunity Act (SIA) and the US Foreign Sovereign Immunities Act (FSIA) - which make their identification more complex. Instead of only looking at what courts have stated in their decisions, one must additionally take into account the effect of the decisions in light of the relevant applicable international law principles. This includes the principle of enforceability found in Article I New York Convention as well as the general principle that state immunity excludes enforcement jurisdiction insofar as such jurisdiction would breach the foreign state's sovereignty. Section 9 SIA and $\$ 1605(6)$ both provide the exception from a state's otherwise available immunity with respect to court proceedings relating to arbitration. English courts have consistently declared awards enforceable against foreign states stating that such power falls within the section 9 exception. ${ }^{53}$ This practice, which also encompasses the power of courts to review the award under the applicable law, is nicely demonstrated by the Svenska Petroleum decision. ${ }^{54}$ Svenska received an arbitral award against the Republic of Lithuania in an ICC Tribunal sitting in Denmark which arose out of the failed exploitation of its oil fields in Lithuania. ${ }^{55}$ Lithuania

\footnotetext{
${ }^{51}$ See, e.g., Bundesgerichtshof [BGH] [Federal Court of Justice], Case No. III ZB 40/12, para. 14, (Jan. 30, 2013), https://juris. bundesgerichtshof.de/cgi-bin/rechtsprechung/document.py?Gericht=bgh\&Art=en\&sid=e1cb08ce86eef36cafce617600cd6038\& $\mathrm{nr}=63472 \& \mathrm{pos}=2 \& \mathrm{xanz}=3$ (Ger.).

${ }^{52}$ Similarly, see Bundesgerichtshof [BGH] [Federal Court of Justice] Case No. III ZB 97/06, (Apr. 17, 2008), https://juris. bundesgerichtshof.de/cgi-bin/rechtsprechung/document.py?Gericht=bgh\&Art=en\&sid=d6d80be0e307bf218606a7751196f023\& $\mathrm{nr}=43773 \&$ pos $=0 \& a n z=1$ (Ger.); Oberlandesgericht [OLGZ] [higher regional court] Dec. 15, 2019, I-4 Sch 10/09 (Ger.); Germany No. 135, Seller v. Buyer, in XXXV Y.B. COM. ARB. 35, 386-88 (Albert Jan Van der Berg ed., 2010).

${ }^{53}$ LR Avionics Techs. Ltd. v. Nigeria [2016] EWHC (Comm) 1761 (Eng.); NML Cap. Ltd. v. Republic of Argentina [2001] UKSC 11, [2011] 2 AC 495 (appeal taken from Eng.); Dallah Real Est. v. Minister of Religious Affs., Gov't of Pak. [2010] UKSC 46, [2011] 1 AC 763 (appeal taken from Eng.); Svenska Petroleum Expl. AB v. Gov't of the Republic of Lith., AB Geonafta [2006] EWCA (Civ) 1529 (Eng.).

${ }^{54}$ Svenska Petroleum Expl. AB v. Gov't of the Republic of Lith., AB Geonafta [2006] EWCA (Civ) 1529 (Eng.).

${ }^{55} I d$. at para. 116 .
} 
applied to appeal a decision declaring the award obtained against it as enforceable on the basis of its immunity. Svenska claimed that Lithuania had waived its entitlement to rely on immunity by agreeing to arbitration, enforcement of the award in domestic courts being a corollary of this agreement which was excluded from the scope of the SIA 1978 under section 9. In reviewing whether Lithuania was entitled to immunity, the UK court considered this as a preliminary question concerning its own jurisdiction. It reviewed the arbitral tribunal's decision under the applicable Lithuanian law. ${ }^{56}$ The exercise of the court's decision-making authority to examine this question demonstrates that immunity does not exclude its power to at least declare an award enforceable. Consistent exercises to this effect in UK courts are generally reflective of the approach of UK courts that at least their power to declare the award enforceable within the meaning of section 101 EAA is not excluded by principles of immunity. ${ }^{57}$

Similarly, United States' courts have rendered decisions against states to confirmed arbitration awards, finding that the jurisdiction to do so falls within $\$ 1605(\mathrm{a})(6)$ FSIA and thus is not excluded by the principle of immunity. For example, in the 1995 Creighton Limited decision, Creighton commenced proceedings in United States court for confirmation of an award rendered against the State of Qatar in France. ${ }^{58}$ The court considered the question of its own jurisdiction within the scope of the FSIA finding that, both as a matter of precedent as well as principle, the provision would not, in principle, exclude the court's jurisdiction to confirm the award. This principle applied regardless of whether Qatar was signatory to the New York Convention or not. This point was later appealed in the 1999 Creighton decision which found that the court lacked sufficient contacts as a matter of private international law to exercise jurisdiction. ${ }^{59}$ However, this decision ought to be viewed as an anomaly in light of the wider consistent practice of United States' courts, to the effect that recognition and review jurisdiction is generally available regardless of the principle of immunity and regardless of the particular treaty or set of arbitration rules which govern the parties' agreement. ${ }^{60}$

\section{Execution Jurisdiction}

The treaty basis for execution jurisdiction - that is, the power to execute against assets pursuant to an award-is less clear. The obligation to recognize and enforce arbitral awards under the New York Convention is generally interpreted as a source for court power to declare the award enforceable but not to execute against assets. ${ }^{61}$

\footnotetext{
${ }^{56} I d$. at paras. 17-29. This related to the subjective interpretation of the contract relating to the "real intention" of the parties "without being limited by the literal meaning of the words."

${ }^{57}$ See, e.g., LR Avionics Techs. Ltd. v. Nigeria [2016] EWHC (Comm) 1761 (Eng.); NML Cap. Ltd. v. Republic of Argentina [2001] UKSC 11, [2011] 2 AC 495 (appeal taken from Eng.); for the scope of its power to review whether there is a valid arbitration agreement as not being excluded by immunity, see Dallah Real Est. v. Minister of Religious Affs., Gov't of Pak. [2010] UKSC 46, [2011] 1 AC 763 (appeal taken from Eng.).

${ }^{58}$ Creighton Ltd. v. Gov't of Qatar, 181 F.3d 118 (D.C. 1999) (though the award was ultimately not confirmed as the court recognized the French decision to suspend the award).

${ }^{59} \mathrm{Id}$.

${ }^{60}$ See, e.g., Stati v Republic of Kaz., 199 F.Supp. $3 d 179$ (D.C. 2016) (award rendered enforceable against Republic of Kazakhstan on basis that valid agreement to arbitrate and thus no immunity due to the state's effective waiver in accordance with $\$ 1605(a)(1)$ ); Blue Ridge, Invs., LLC v. Republic of Arg., 902 F.Supp. $2 d 367$ (S.D.N.Y. 2012) (ICSID was treated as a justification, though the not source for court authority to confirm an award under $\$ 1605$ (a)(6) by interpreting Argentina's consent to ICSID as a waiver of immunity); PAO Tatneft v. Ukraine, Civil Action No. 17-582, 2020 U.S. Dist. LEXIS 152856 (D.D.C. 2018).

${ }^{61}$ See, e.g., CBF Industria De Gusa v. AMCI Holdings, Inc., 850 F.3d 58 (2d Cir. 2017); Mobil Cerro Negro, Ltd. v. Bolivarian Republic of Venez., 87 F.Supp. 3d 573 (S.D.N.Y. 2015) (under the ICSID Convention, it is stated that similarly "conversion of an arbitral award into a judgment allows a creditor to begin to enforce the award, for instance, by attaching or executing on assets"); even where the New York Convention is mentioned as part of the reasoning relating to attachment orders, it is of the source of that authority: Mobil Cerro Negro ltd. v. Petroleos De Venezuela [2008] EWHC (Comm) 532 [45] (UK).
} 
However, there is a growing harmonized approach as between the examined courts that execution against commercial assets of a foreign state falls within the scope of a court's international adjudicative authority - that is, irrespective of any link to the jurisdiction. This is evidenced, again, by exercises of decision-making authority of national courts and decisions to this effect, for example, for what they say.

To demonstrate this approach, the decision in Creighton v. Qatar ${ }^{62}$ is a useful starting point because, as explained above, immunities are a direct source of jurisdiction in the civil law states examined. Thus, the decisions, for what they say-and not merely their effect-are also representative of the approach being examined herein. Creighton, a French company, obtained an award against the Government of Qatar and sought to enforce against assets of Qatar in France. The question of whether the court could order the execution measure was one which arose "in light of principles of public international law concerning immunities of the foreign state." The court ultimately ordered the execution measure against the assets of Qatar, which were held for commercial purposes, finding that was sufficient once "the arbitral award [became] definitive." Consequently, provided that the award has passed through the recognition and review process - for example, it is valid in accordance with the standards of the New York Convention-the French approach is that execution against commercial assets is generally permitted as an aspect of the court's international adjudicative authority. ${ }^{63}$

Similarly, consistent statements by German courts confirm the general availability of execution jurisdiction (Zwangsvollstreckung) as an aspect of the court's international adjudicative authority. For example, in the Walter Bau decision discussed above, though it concerned recognition jurisdiction, the court also made a clear statement with regard to the availability of its jurisdiction in respect of execution:

German jurisdiction does not extend to foreign insofar as they enjoy immunities. Consequently, the limits of immunity are different in respect of recognition and compulsory enforcement-for example, execution-proceedings depending on their effects... with regard to recognition proceedings, immunity is available according to general public international law insofar as the sovereign activities of the foreign state are affected by the legal dispute whereas immunity in execution proceedings is determined according to the capacity in which the foreign State possesses the asset. ${ }^{64}$

There is consistent practice to the effect that German courts have granted execution against commercial assets of the foreign State. ${ }^{65}$ By virtue of that exercise of jurisdiction in respect of

\footnotetext{
${ }^{62}$ Cour d'appel [CA] [regional court of appeal] Paris, civ., Dec. 12, 2001, Creighton Ltd v. ministère des finances et ministère des Affaires municipales et de l'Agriculture du gouvernement de l'etat du Qatar (Fr.).

${ }^{63}$ See Cour d'appel [CA] [regional court of appeal] Paris, civ., May 19, 2015, Société Chematur AB v. République de Bulgarie (execution permitted against Republic of Bulgaria's provisional mortgages on real estate within the jurisdiction) (Fr.); Cour d'appel [CA] [regional court of appeal] Paris, civ., Jan. 31, 2013, Société Orion Satellite Communications Inc. v. société Federal State Unitary Entreprise "Russian Satellite Company"(conservatory measure against assets within the jurisdiction permitted in principle) (Fr.).

${ }^{64}$ Translation by the author ("Die deutsche Gerichtsbarkeit erstreckt sich nicht auf ausländische Staaten, soweit sie Immunität genießen. Dabei verlaufen die Grenzen der Immunität im Erkenntnisverfahren und im Vollstreckungsverfahren anders ... Im Erkenntnisverfahren besteht nach allgemeinem Völkerrecht Immunität, soweit die hoheitliche Betätigung des ausländischen Staats durch den Rechtsstreit betroffen ist, im Zwangsvollstreckungsverfahren bestimmt sich die Immunität danach, ob der ausländische Staat das Vollstreckungsobjekt als Hoheitsträger besitzt (vgl. Geimer, IZPR, 6. Aufl., Rn. 562).

${ }^{65}$ See, e.g., Bundesgerichtshof [BGH] [Federal Court of Justice] Oct. 4, 2005, Germany No. 92 / W2, Franz J. Sedelmayer (Germany) v. Russian Federation, Deutsche Lufthansa AG (Germany), in XXXV Y.B. Com. ARB. 31, at 707-17 (Albert Jan Van der Berg ed., 2006) (attachment granted in respect of commercial bank accounts held on behalf of the Russian Federation, presumed not excluded by immunity); Oberlandesgericht [OLGZ] [Higher Regional Court] Oct. 1, 1998, IPRax (1999, no. 4) 247-51. An ICC award was obtained against the State of Iraq in Paris; JGV, a German and Italian joint venture company, brought an action pursuant to the award in the Court of First Instance of Frankfurt seeking to attach assets held by the Central
} 
the foreign state, the courts have thus consistently accepted that such jurisdiction is not excluded by international principles of immunity.

The UK approach arises under Section 72.2 CPR Rules which provides UK courts with the power to issue third-party debt orders to enforce against assets which are "due or accruing due by the third-party to the judgment debtor." UK courts have consistently interpreted this provision in the context of international arbitrations to order execution against commercial assets within the jurisdiction ${ }^{66}$ and has implied it would also have the power to grant such an order against assets outside the jurisdiction where such an order would be recognized by the foreign state's law. ${ }^{67}$ This latter question arose in the decision of Société Eram which was not itself an arbitration case, but was later relied on in the context of whether an attachment order could be granted against Iraqi assets in the Taurus Petroleum decision which did concern execution against assets of a foreign State pursuant to an arbitral award. ${ }^{68}$ In Sociéte Eram, the assets with respect to which a garnishment order was sought to discharge a debt owed to the Romanian shipping company, Société Eram, were located in Hong Kong. Although the court ultimately found it lacked jurisdiction to grant the order, it did so on the basis that the law which governed the debt, Hong Kong law, would not recognize such an order and thus it would be rendered ineffective. Thus, it was a matter of practicality rather than principle that the order was not made. In principle, the court did not exclude that a third-party debt order could be granted in circumstances in which such a debt would be discharged in the foreign jurisdiction. In Taurus Petroleum, for example, the court relied on this principle to find that the UK court would have jurisdiction, in principle, to issue a third-party debt order against the State of Iraq in respect to assets owed by it under a letter of credit to a Swiss company under an arbitration award. The court exercised jurisdiction on this basis regardless of the manner in which the assets were held. This implies that, similar to the German approach, execution jurisdiction is an available aspect of court's international adjudicative authority and the question of whether the particular assets may be executed against is a sui generis question relating to the law of state immunity.

Finally, United States' courts have adopted an approach whereby execution may generally be ordered against assets within the jurisdiction pursuant to Federal Rule of Civil Procedure (FRCP) 69(a)(1) because such jurisdiction falls within the court's jurisdiction. This can be demonstrated by the decision in Ocean Warehousing. ${ }^{69}$ An award had been obtained in Dutch arbitration proceedings and an ex parte attachment had been granted by a United States' court against the debtor's assets in the United States. On appeal, the United States court affirmed the decision pursuant to FRCP 64 together with Article 62 New York Civil Practice Law. ${ }^{70}$ FRCP 69 is a more general provision with regard to execution under a money judgment, whereas FRCP 64 allows an individual state's court within the United States to grant a remedy for seizure of a person or property to secure satisfaction of a judgment. Article 62(5) New York Civil Practice Law provides that "full faith and credit" should be given to provide for attachment based on a judgment which qualifies for recognition under Article 53. Article 53 allows for the recognition of foreign country judgments. This is reflective of a wider approach which treats execution jurisdiction as a generally

Bank of Iraq (CBI). The First Court granted attachment. The State of Iraq appealed, arguing CBI was a separate legal entity are thus immune under Iraqi law. The Court affirmed the Lower Court's decision, finding that because the assets were not used in relation to the sovereign activities of Iraq, they were not immune from execution).

${ }^{66}$ Hardy Expl. \& Prod., Inc. v. Gov't of India [2018] EWHC (Comm.) 1916 (UK); AIG Cap. Partners, Inc. v. Republic of Kaz. [2005] EWHC (Comm.) 2239 (Eng.).

${ }^{67}$ Société Eram Shipping Co Ltd v. Compagnie Internationale de Navigation [2003] UKHL 30 (appeal taken from Eng.). Though the third party debt order was not granted in respect of a debt in Hong Kong, the court stated it could grant such an order if Hong Kong law would have recognized such an order.

${ }^{68}$ Taurus Petroleum Ltd. v. State Oil Mktg. Co., Republic of Iraq [2017] UKSC 64 (UK).

${ }^{69}$ Ocean Warehousing B.V. v. Baron Metals \& Alloys Inc., 157 F.Supp. $2 d 245$ (S.D.N.Y. 2001).

${ }^{70} I d$. 
available aspect of the court's international adjudicative authority because it is consistent in cases where there is no link between the court's territorial jurisdiction and the arbitration. ${ }^{71}$

It is necessary again to consider whether this norm would breach the international principle of state immunity according to which a state may not exercise jurisdiction over a foreign state insofar as it breaches the foreign state's sovereignty. ${ }^{72}$ Execution measures may be perceived as more coercive in their intended effects than supportive or recognition measures. However, they ultimately embody a converted arbitral award. Put differently, provided that the arbitral award is found valid under the applicable law - an additional step to the enforcement process which is currently found at the recognition stage - then execution against assets within the state where execution is sought ought to be justified on the basis of that decision where the assets are also held for commercial purposes. ${ }^{73}$

\section{E. Conclusions}

This Article has demonstrated that a common approach has emerged concerning the scope of national court "enforcement jurisdiction" in respect of international arbitral tribunals. This has been achieved, in part, in adopting a wider definition to "enforcement jurisdiction" than is usually used in public international law - as not merely compelling a state to do something, but also inducing its compliance. The analysis has also been based on decisions from representative states: United Kingdom, United States, France, and Germany. These are 'representative' in the sense that they are one non-federal common law, one federal common law, one non-federal civil law and one civil law court.

According to this set of practice, the international principle of state immunity does not prima facie exclude the jurisdiction but merely operates as an exception to it. This is because, as demonstrated by the consistent approaches of the representative courts, this approach arises as an aspect of the court's adjudicative authority, irrespective of any link to the jurisdiction. Furthermore, as demonstrated by this Article, this practice is in accordance with the applicable international principles relating to arbitration and state immunity found in various international and national harmonizing instruments. This is because it was only analyzed insofar as it was consistent with those instruments which apply to the scope of court enforcement jurisdiction.

The identification of this practice suggests that amendments should be made to various harmonizing laws to reflect the changing law. For example, Article 17 UNCSI provides an "arbitration exception" from a state's otherwise available immunity which is said to derive from the "effect of the arbitration agreement." This exclusion of immunity is stated to extend only to proceedings relating to "(a) the validity, interpretation or application of the arbitration agreement; (b) the arbitration procedure; or (c) the confirmation or the setting aside of the award." Apart from the fact that the idea of immunity as the rule-rather than the exception to the rule in the context of arbitration-related court proceedings - is being contested as a point of principle throughout this Article, ${ }^{74}$ Article 17 also does not encompass the full extent of national court enforcement

\footnotetext{
${ }^{71}$ See, e.g., Karaha Bodas Co., LLC v. Perusahaan Pertambangan Minyak Dan Gas Bumi Negara, 364 F.3d 274, (5th Cir. 2004) (in considering whether to uphold a preliminary injunction to restrain US proceedings for enforcement, court found that Indonesian court proceedings for enforcement against assets did not undermine a US court's jurisdiction to enforce); Huntington Ingalls Inc. v. Ministry of Def. of the Bolivarian Republic of Venez., No. 1:18-cv-0469, 2019 U.S. Dist. LEXIS 99204 (D.D.C. 2019) (recognizing execution under Fed.R.Civ.P. 69(a)(1) applies equally to international arbitral awards when exequatur has already been obtained).

${ }^{72}$ The main principle of state immunity, as set out in the introduction. See Fox \& WEBB, supra note 2, at 1.

${ }^{73}$ These have been the two consistent features of the decisions examined. See, e.g., Hardy Expl. \& Prod., Inc. v. Gov't of India [2018] EWHC (Comm.) 1916 (UK); Karaha Bodas Co., LLC v. Perusahaan Pertambangan Minyak Dan Gas Bumi Negara, 364 F.3d 274, (5th Cir 2004). Compare Société Eram Shipping Co Ltd v. Compagnie Internationale de Navigation [2003] UKHL 30 (appeal taken from Eng.), with Sedelmayer, supra note 64 (where execution not available in respect of assets held for sovereign purposes).

${ }^{74}$ Due to the emergence of the "lex generalis" relating to international arbitrations.
} 
authority which is available with respect to international arbitrations. As demonstrated by the last section, it also extends to execution proceedings to enforce against assets of the foreign state provided these are held for commercial purposes. Put differently, national courts ought to be obliged to exercise these forms of enforcement jurisdiction irrespective of immunities. Further work could examine the more precise content of any such principles or rules and the extent to which they may be regarded as a possible source of public international law. ${ }^{75}$

\footnotetext{
${ }^{75}$ The practice might crystallize, for example, as a customary international law principle (Article 38(1)(b) ICJ Statute) or a general principle of international law (Article 38(1)(c) ICJ Statute).

Cite this article: Talwar Mouland S (2021). Immunities And Arbitration: A New Lex Specialis Regime. German Law Journal 22, 1555-1568. https://doi.org/10.1017/glj.2021.75
} 